\title{
Role of Communication Skills in The Success of Business Firms
}

\author{
Shivangi Saxena, Research Scholar, Kumaun University Nainital(Uttarakhand), India. \\ Dr. Mukesh Joshi, Associate Professor, Radhe Hari Government PG College Kashipur, India.
}

Abstract - A best way to define the objectives and plan according to that can be done through proper communication. Communication is very important function to be included in management for success of any business organization . For better running of business it is important that there must be proper communication between superior and subordinate. Managers and employees must be good communicator. There should be proper channel to communicate in the firm.when people communicate for any sort of work it is always profitable for all to get clear ideas of work. Clarifying ideas, thoughts, communicating policies and procedure, listening to grievances ,asking for suggestion, all these discussion can only be done through proper communication skills among the people .Bad communication lead to poor functioning of business activities. Our main aim in this research paper is to highlight the role of communication in any business organization. At personal and professional level it must be clear that survival and success of any organization depends upon the good communication skills.

Keywords:- Body language, Communication, Coordination, Efficiency, Motivation, Personality.

\section{INTRODUCTION}

Communication is a process to exchange expression, ideas, messages, emotions, thoughts, feelings among people. It is the most appropriate way to understand someone and his messages, that what he want to make other people understand. It generate a mutual relation between speaker and a receiver. It make a social contract between two or more people by sharing information and message. It is infact a major phenomenon for existing and social organization. Communication is very helpful in bringing a positive change in society as man is a social being and he like to communicate with others. Nobody in this world can survive alone, every person need a companion to express his/her feelings and this is only possible when communicated properly and clearly. Communication can be of many type -Formal communication, Informal communication, Verbal communication, Non-verbal communication, Gestural communication. Many people are born with a talent to communicate but there is a need to learn how to communicate effectively. We learn things by others, it is not possible every time to generate knowledge by own. We observe people and learn new skills through them. Communication is very important process in our personal as well as professional life. Communication is a lifeblood of organization for carrying out various business activities . Communication is needed to plan a business activities, manage them, organise them and achieve its objective. It leads to success.

\section{COMMUNICATION-A PROCESS OF} CHANGE

In this connection it is important to note that the world is changing fast , and with it every organization is becoming more and more sophisticated. So, communication has first of all to be given due recognition as an integral part of process of change. whenever a change in the direction of technology, structures, objectives, etc, is called for it becomes easier with the help of communication . Most of the management problem arise because of lack of effective communication. If the communication system is properly devised the chances of misrepresentation and misunderstanding are minimized. If the managers are not aware of the relations and felings of their subordinates their planning will collapse and numeral obstaccles will crop up.[1]

\section{IMPORTANCE OF COMMUNICATION IN THE ORGANIZATION}

Communication is very important for every person in an organization, especially for managers to manage all the other activities of business. Some of the importance of communication are mentioned below:

1) For motivation:- Effective communication is very important to motivate the employees of the organization as they will feel motivated when they will feel free to communicate with their superiors and collegues .and the task they have to perform is clarified to them through communication. 
2) Raise the morale of employees:- It helps in raising the morale of employees ,because it bring zeal in their work at the workplace .

3) Progress of carrier:- In any organization interaction with clients, colleagues, and superiors is very important.we need to discuss our problems, interact with each other, give and take interactions. when a person is able to deliver his or her messages clearly and is able to understand others is most important task to work effeciently.and it brings the growth to the carrier.

4) Development of rapport:- Any customer get happy when the company understand their demands. and to satisfy the customer it is needed to have acontact with them, it can be face to face or on mails and telephone.

5) Maintain relation:- Proper communication is very important to maintain relations with clients and colleagues that enhance the confidence level and bring development in one self.

6) Influencing people:- Through communication a person is able to influence others by expressing their feelings to others. Communication skills help you to gather information and express your feelings in more better and clear way.

\section{COMMUNICATION STRATEGIES}

The strategy for internal communications should be based on analyses of:

What management want to say :- what management want to say depends on assesment of what employees need to know, which, in turn, is affected by what they want to hear.

Management usually aims to achieve three things : first, to get employees to understand accept what management proposes to do in areas that affect them ; second, to obtain the commitment of employees to the objectives ,plans and values of the organization, and, third to help employees to appericiate more clearly the contributionthey make to organizational success and how it will benefit them.

What employees want to hear:- clearly, employees want to hear about to comment upon the matters that effect their interests . these will include changes in working methods and conditions,changes in the arrangements for overtime and shift working,company plans which may affect pay or security,and changes in terms and conditions of employment.

Analysing communication problems:-problems with channels of communication can be dealt with by intoducing new and improved communication systems.lack of skill is a matter for education and training.[2]

\section{PROCESS OF COMMUNICATION:}

Process of communication are the steps to carry of communication in a systematic way. these are mentioned below:
- Sender: sender is a person who thinks of an idea . He is a first person in communication process. After thinking of an idea he encodes it to send it to receiver.

- Transmission : It is a channel on which message is transmitted to the receiver. Channel connects a sender to the receiver.

- Noise: Noise is a obstacle that create a hindrance in the process of communication. So, sender should choose a channel that is free from noise.

- Receiver: Receiver is a person who receive the message.after receiving the message receiver decodes the message and understand it.

- Feedback: feedback is very important in communication process as it gives and idea that message is transmitted and received successfully.

\section{NEED OF COMMUNICATION:}

1) Motivation -Motivated employees are an asset to a business organisation. Effective communication centres round the usage of words, speed of delivery of words, pitch modulation and body language. Using the right tools to communicate the right messages at the right time can salvage a crisis and motivate people to work towards success. Motivated employees ensure not only the smooth and efficient functioning of an organisation but also increased production, sales, and profits without supervision.

2) Impress the clients- One needs good communication skills to impress the client through oral communication. Now oral presentation can be best defined as a person proposing a speech to an audience. Oral presentation is a common tool used in business, which it is often used in business meetings. An oral presentation can produce a significant amount of impact to the audience; if the purpose is to convince the audience then an oral presentation is used to persuade the audience.

3) Raising Morale - Morale means "the capacity of a group of people to pull together persistently and consistently in pursuit of a common purpose". It is the product of motivation, which leads to zeal for action. The morale of the employees fluctuates time to time. Authorities should therefore use effect communication to keep their morale high.

4) Business proposal - Business proposal is crucial for anyone who needs to obtain capital for business. If you seek out Venture Capitalists or Angel Investors, most will not even talk to you unless you have a well written business proposal. Many business ideas require a large amount of capital, and this capital can only be obtained from three sources. This is either through loans, using your own money, or getting an investor to invest in it.

5) Facilitate business meetings - Facilitation is the technique or skill of organizing a business meeting. 
6) Managerial efficiency: - Communication helps in smooth operation of management. Managerial task can only be performed when communication system is effective.

7) Better decision: - The success of organization can be measured in better decision. When the information, data and other fact are not effectively communicated, it hampers the decision making. So, when the facts are communicates to concerned department, organization and person. It is easy to make decisions promptly. [3]

\section{MANAGEMENT COMMUNICATION IN AN ORGANISATION:}

As a management tool, communication intends to establish good interpersonal relationship, non-confrontational and based on achievement of common goals ,to increase the level of skills.[4]

Communication is a key mechanism for achieving integration and coordination of the activities of specialised units as different levels in the organization.[5] Managers should be a skillfull communicator. they must have an idea of how to speak, and how to make people understand what to speak. for performing managerial work it is important to know the communication skills. they must have talent of planning everything in the business and to organise people and working so as to achieve desired result. Basically there are two types of communication -formal and informal . but every organization follows the formal communication.

Formal communication is an exchange of official information that flows along the different levels of organisational hierchy and conforms to the prescribed professional rules, policy, standards, processes, and regulation of the organization. [6]

Managing a business is a very important task by the managers .They have many responsibilities. Some are mentioned below:-

- To stand as supporting system of organization.

- To supervise, guide and support employees.

- To manage the working system.

- To communicate all the policies ,procedure, rules to the employees.

- To provide superiors with the suggestions and grievances of employees.

\section{TECHNIQUES TO IMPROVE COMMUNICATION SKILLS IN AN ORGANIZATION:}

1) Listening should be increased:- Listening to be encouraged as it helps us to understand the message and communication properly.

2) Whom you are talking to matters:- It is okay to use acronyms and informal language when you are communicating with a buddy ,but if you are emailing and texting your boss, any informal language, has no place in your message.[7]
3) Body language :- messages are non verbal in many of the cases so sender must know how to respond through body signals.

4) Eye contact:-eye contract is necessary to know that to whom one is communicating with.

5) Make communication a priority:- Take classess, read books, magazines, articles or learn from successful communicators around you. seek a mentor or coach.[8]

6) Learn the basics of nonverbal communication:-To communicate clearly and confidently,adopt proper postures. Avoid slouching,folding your arms or make yourself appear smaller than you are.[9]

7) Questioning skills:- Questioning is a crucial skill to ensure that you have understood someone's message correctly. It is also a very good way of obtaining more information about a particular topic,or simply starting a conversation and keeping it going.[10]

\section{CONCLUSION}

In this paper we proposed different strategies, needs process and techniques of communication. Communication skills are very important for any working place. And this can be acquired by observing people and learning through them. As an individual every person should learn as how to interect with others. If communication is done in a proper way it can solve many problems. With the enhancement of technologies communication has also become very easy as it increased the channels of communication. It is very important for career improvement and achieving goals and also for the development of ones own personality.

\section{REFERENCES}

[1] Sinha,k.k : Business communication : PN.9 : Published by Galgotia publishing company New delhi : 4th edition: ISBN-81-85989-36-2 : 2012

[2] Armstrong,Michael : A handbook of human resource management practice : PN-819,821 : Published by kogan page limited : 10th edition : ISBN 0-7494-4631-5 : 2006

[3] Mahajan ,Rajendra : The key role of communication skills in the life of professional : P.N-36-39 : IOSR Journal of humanities and social science(IOSR-JHSS) : Volume 20,issue 12,ver.2 : e ISSN -22790837, P ISSN-2279-0845 : Dec 2015

[4] Bucata, george ,Alexandru marius rizescu : The role of communication in enhancing work effectiveness of an organization: P.N-50: Land forces academy review vol.XXII,no.1(85) : 2017

[5] Radovic m.markovic: Organizational behaviour and culture, globalisation and the changing environment of organisations : PN-348

[6] Https://businessjargons.com/formal communication html : 7-10-2019

[7] Https://www.right.com/WPS/WCM/connect/rightusen/home/thought wire/categories/ career work/10-ways-to-improve-yourcommunication-skills : 13-10-2019

[8] Https://garfinkleexecutivecoaching.com/articles/improve your communication skills/9-tips-for-improving your-communicationskills: $13-10-2019$

[9] Https://www-entrepreneur-com.cdn.ampproject.org : 14 proven ways to improve your communication skills: 29-01-2020

[10] Https://www.skillsyouneed.com/ips/improving-communication.html : 29-01-2020. 